
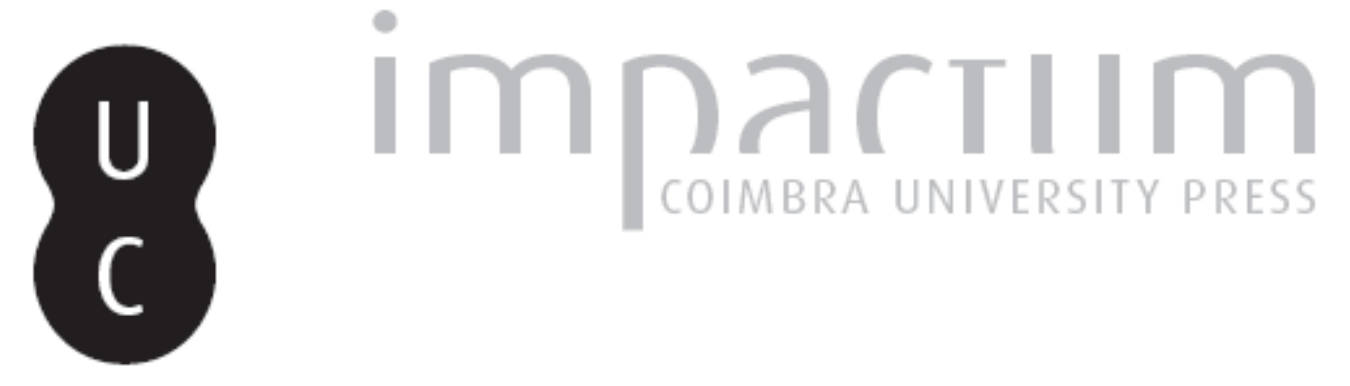

\title{
Episódio das ITAl e o destino de Aquiles
}

Autor(es): $\quad$ Carvalho, Sofia Daniela Gil de

Publicado por: Imprensa da Universidade de Coimbra

URL persistente:

URl:http://hdl.handle.net/10316.2/34001

DOI:

DOI:http://dx.doi.org/10.14195/0872-2110_58_5

Accessed : $\quad$ 26-Apr-2023 14:18:25

A navegação consulta e descarregamento dos títulos inseridos nas Bibliotecas Digitais UC Digitalis, UC Pombalina e UC Impactum, pressupõem a aceitação plena e sem reservas dos Termos e Condições de Uso destas Bibliotecas Digitais, disponíveis em https://digitalis.uc.pt/pt-pt/termos.

Conforme exposto nos referidos Termos e Condições de Uso, o descarregamento de títulos de acesso restrito requer uma licença válida de autorização devendo o utilizador aceder ao(s) documento(s) a partir de um endereço de IP da instituição detentora da supramencionada licença.

Ao utilizador é apenas permitido o descarregamento para uso pessoal, pelo que o emprego do(s) título(s) descarregado(s) para outro fim, designadamente comercial, carece de autorização do respetivo autor ou editor da obra.

Na medida em que todas as obras da UC Digitalis se encontram protegidas pelo Código do Direito de Autor e Direitos Conexos e demais legislação aplicável, toda a cópia, parcial ou total, deste documento, nos casos em que é legalmente admitida, deverá conter ou fazer-se acompanhar por este aviso.

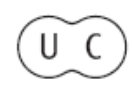


COIMBRA • 2013
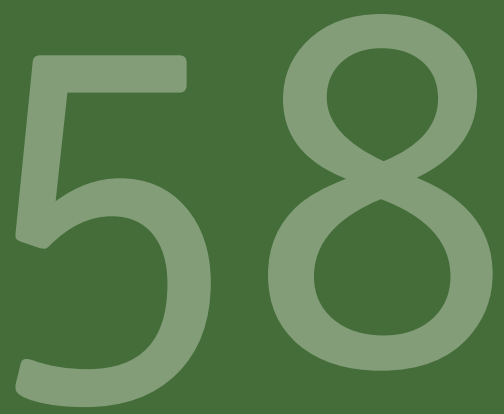

BOLETIM DE

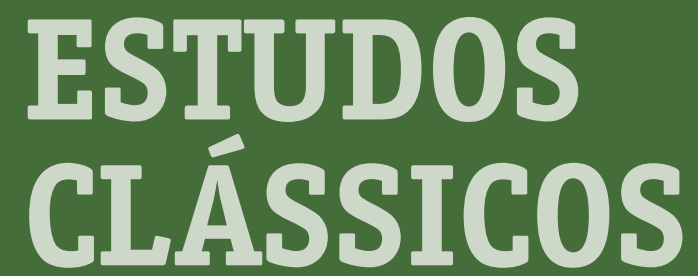

\author{
ASSOCIAÇÃO \\ PORTUGUESA \\ DE ESTUDOS \\ CLÁSSICOS \\ INSTITUTO \\ DE ESTUDOS \\ CLÁSSICOS
}




\title{
0 EPISÓDIO DAS $\Lambda$ ITAI E 0 DESTINO DE AQUILES
}

\author{
SOFIA DANIELA GIL DE CARVALHO
}

A estrutura da Ilíada é algo que tem, desde a Antiguidade, intrigado escolásticos e estudiosos desta que é a primeira obra que nos chegou escrita em Grego. ${ }^{1}$ No presente ensaio detemo-nos no aspeto da recusa das preces por parte de Aquiles no Canto 9. Este tópico tem dividido os estudiosos ao longo das gerações: uns tendem a ver a intransigência de Aquiles como segunda etapa da consumação da sua cólera, que é apanágio de todo o poema; outros tomam a recusa como uma inevitabilidade do destino da personagem de Aquiles.

Na estrutura da Ilíada, os episódios de súplica representam importantes momentos no caminho da narrativa, quer por configurarem pontos de viragem (e.g. as súplicas de Crises 1. 17-21 e as da Embaixada a Aquiles 9. 225-sqq), quer por ilustrarem momentos de ira ou de desvario que caraterizam determinada personagem (e.g. a compaixão de Menelau para com Adrasto a 6. 45-50 ou a crueldade de Agamémnon a 11.130-5). Cumprindo diferentes funções no enredo, o motivo da súplica é recorrente no poema de Homero. ${ }^{2}$ Repare-se que a Ilíada principia e termina com episódios de súplica, onde o paradigma se repete: um troiano dirige-se ao acampamento aqueu para suplicar a devolução de um filho. Já as respostas e atitudes para com o suplicante diferem diametralmente.

1 Para discussão recente desta problemática vide West (2011).

2 Cf. Gould (1973: 74-103); Pedrick (1982: 125-40); Thornton (1984: 113-143); Cairns (1993: 118-9); Lynn-George (1996: 1-26). 
No Canto 1, assistimos à súplica de Crises a Agamémnon. Crises, sacerdote de Apolo, vem como suplicante pedir que os Aqueus lhe restituam a filha. Agamémnon, insensível ao pedido do sacerdote, recusa. Perante o ultraje a que o seu sacerdote é sujeito, Apolo - atento à prece de Crises - concede-lhe que o seu inimigo, o rei de Micenas e suas hostes, sofra males imensos, males que se convertem numa peste que toma repercussões assustadoras para os Aqueus. Urge uma solução e Aquiles, convocando a Assembleia, convida Calcas, adivinho, a proferir a razão pela qual Apolo se enfurecera com os Aqueus: Agamémnon não quis devolver Criseida a seu pai. Aquiles procura acerrimamente persuadir o rei a devolver a filha ao pai. O Atrida - revoltado com o facto de ter de abdicar de um prémio seu, restitui a donzela a seu pai, ficando, em troca, com o prémio de Aquiles: Briseida - insulta Aquiles que, perante a ofensa, se retira da guerra. A ausência do Pelida, por sua vez, conduzirá a um forte decréscimo do sucesso aqueu face às hostes troianas.

O mesmo motivo - a súplica pela devolução de um filho, embora morto - é o que leva Príamo à tenda de Aquiles no Canto 24. Tal como o sacerdote de Apolo, também o rei de Tróia age em desespero. Este episódio, repleto de vocabulário de súplica (24.356-7, 467, 485, 502, 570), dos mais comoventes do poema, é bem conhecido e sobre a súplica nele presente já muito se disse. ${ }^{3}$ Porém, interessa destacar que esta súplica - que quebra o ciclo de súplicas a que Aquiles não atende ${ }^{4}$ - apela à piedade do Pelida evocando a figura paterna e o seu sofrimento pela prole (24. 466-7, 486-494), figuras que, de resto, abundam no discurso de Fénix no Canto 9. Esta referência leva o herói às lágrimas, toca-lhe o coração, livrando-o, assim, da ira funesta. Aquiles e Príamo (bem como Crises, que perdeu a sua filha para a escravatura) suportam a mesma dor: a perda das pessoas que mais amavam.

3 Cf. supra n. 1.

4 Cf. Rosner (1976: 314-327). 
Ao mesmo pedido Agamémnon e Aquiles respondem de forma diferente. Este trivial pormenor, evidente na sua função narrativa de caraterizar as personagens, revela-se decisivo na interpretação do pedido de Agamémnon a Aquiles. Se o Atrida está mais interessado em manter os seus despojos de guerra intocáveis (1.29-31), Aquiles, movido no seu coração pela piedade (24. 516 oík $\tau i ́ p \omega v)$ que lhe inspirou a figura de Príamo suplicante, acede ao pedido do rei troiano restituindo-lhe o cadáver de Heitor. As razões que movem estas duas personagens são distintas e é no Canto 9 que esta divergência se acentua com mais clareza.

O contexto e propósito da embaixada enviada por Agamémnon são consideravelmente diferentes dos dois exemplos supramencionados. É que não é movido por força emocional ou relacional que Agamémnon se vê na obrigação de enviar a embaixada a Aquiles, implorando o seu regresso, mas sim por uma necessidade estratégica que o Atrida se compromete a resolver com recurso à diplomacia. Se Crises e Príamo suplicam por amor, o Atrida faz-se dirigir a Aquiles por necessidade.

A diferença de propósito entre as súplicas de Crises e de Príamo e a de Agamémnon deteta-se, desde logo, na elaboração do pedido. Se, por um lado, Crises e Príamo apelam à piedade do destinatário da súplica, Agamémnon preocupa-se em elencar um impressionante catálogo de prémios. A generosa lista (9.115-61) concretiza, por um lado, as palavras de Atena a Aquiles: a recompensa pelo dano (1.211-14) e, por outro, a antecipação de Aquiles que logo no Canto 1, após a troca de insultos entre si e o rei de Micenas, prevê que um dia vai "surgir a necessidade de eu afastar dos outros a desgraça" (1. 340-1). As súplicas do Atrida são para Aquiles a prova clara de que os Aqueus necessitam da sua presença (cf. 9. 197, 309) em ordem a que seja possível a vitória aqueia; não representa, portanto, uma verdadeira súplica, uma redenção sentida. A condição de necessidade do exército aqueu é, de resto, acentuada nos Cantos imediatamente seguintes ao Canto 9 (cf. 10. 118, 172; 11. 609-10), imprimindo na acção a noção de esperança derradeira, de aflição última. 
A distinção de propósito não é, porém, o único fator que diferencia o episódio do Canto 9 das demais cenas de súplica, o que levou à equação da legitimidade da embaixada no conjunto dos momentos de súplica na Ilíada. ${ }^{5}$ Se a descrição das preces de Crises e Príamo pela restituição dos filhos é plena de elementos que marcam a humildade dos suplicantes, o discurso de Agamémnon e todo o episódio da embaixada carece dos preceitos ritualísticos associados a esta instituição.

Na tentativa de recuperar o auxílio de Aquiles, Agamémnon, seguindo a proposta de Nestor (9.96-113), elabora a lista de presentes e nomeia a embaixada (também ideia de Nestor 9. 165-72) que deverá seguir para a tenda de Aquiles.

O discurso de cada embaixador é pensado e indicado por Nestor. Cada um deles cumprirá uma função muito concreta que se encontra em dependência direta do grau de afinidade que o embaixador tem com o Pelida. Esta escala de afetos, como lhe chamou Alden (2000: 241), irá determinar o conteúdo da intervenção dos embaixadores.

Ulisses é o mensageiro de Agamémnon, o diplomata. O seu discurso decalca o catálogo do Atrida. No entanto, o rei de Ítaca não se priva de acrescentar elementos que pudessem contribuir para a comoção de Aquiles: faz o ponto da situação dos Aqueus perante a ameaça da vitória troiana (9.230-48) e repete os conselhos de Peleu a seu filho - o controlo do seu coração, das suas paixões, a escolha pela prudência, pela ponderação (9. 252-9). Só então nomeia o rol de prémios que Agamémnon está disposto a oferecer ao Pelida como símbolo das suas desculpas (9. 264-98). À medida que os objetos são nomeados, a sua descrição é alargada. Se as trípodes e as taças são meramente mencionadas (9.122), os cavalos já merecem que a sua excelência seja assinalada (9. 123-7). Da mesma forma, com a referência às sete mulheres lésbias, Agamémnon relata como as obteve (9.128-30). A devolução de Briseida é acompanhada de

5 Alden (2000: 181-289). 
um juramento (9.131-4) que, por sua vez, coloca o catálogo num plano que extravasa o momento presente reportando-se a um futuro (9.135) dependente da validade do juramento.

Tendo em conta a repetição do enunciado do catálogo de Príamo (cf.

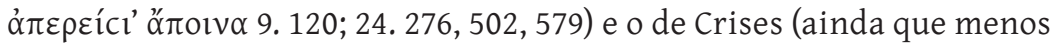
elaborado, 1.13), seria expectável que Agamémnon acabasse por aqui. Porém, o rei de Micenas adiciona mais duas secções ao seu catálogo. Os presentes assumem uma nova dimensão: ecoam os objetos da primeira secção, mas escapam à categoria do mensurável. Aos dez talentos de ouro (9. 122) é sobreposto um navio repleto de ouro e bronze (9.137). Para além de representar uma fuga ao padrão normal deste tipo de catálogos, a própria enumeração dos presentes transporta-nos para uma dimensão temporal que não é a do episódio. ${ }^{6}$

São aspetos de caráter formal que, na retórica de Agamémnon, nos guiam neste sentido. Os verbos que haviam sido conjugados na primeira pessoa são substituídos por imperativos, o que configura um convite claro a aceitar o que Agamémnon está a oferecer.?

O catálogo prevê a vida próspera de Aquiles, caso ele consinta regressar à refrega. Se aceitar, Agamémnon está disposto a fazer cumprir o que prometeu, que é tudo o que um homem pode almejar: ser guerreiro, conquistador e rei. Mas o rei de Micenas não poderá prometer algo contrário ao destino.

Ulisses acrescenta ainda dois argumentos para o regresso de Aquiles ao campo de batalha: mesmo sem perdoar Agamémnon, os restantes camaradas merecem a piedade de Aquiles. Repare-se que as últimas palavras de Agamémnon são omissas (9. 157-160, cf. 9. 299-301):

\footnotetext{
6 Sammons (2008: 365).

7 Ibidem.
} 


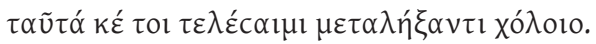

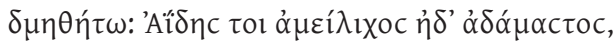

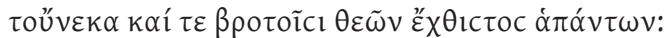

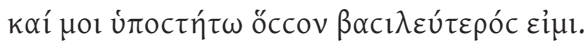

Estas coisas eu cumprirei se ele abandonar a sua cólera.

Que se domine (pois o Hades é inapelável e indomável E por isso é detestado pelos mortais e por todos os deuses)

160 E se submeta a mim, pois sou detentor de mais realeza.

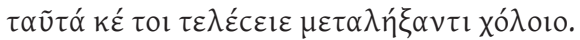

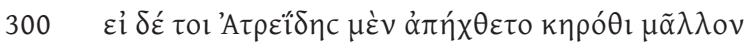

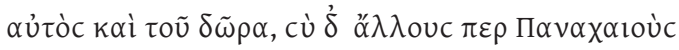

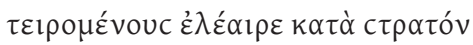

Estas coisas ele cumprirá se tu abandonares a tua cólera.

300 Mas se o Atrida for por ti demasiado detestado em teu coração, Tanto ele como seus dons, compadece-te de todos os outros Aqueus oprimidos no exército.

Em vez de frisar a realeza do Atrida e o seu poder (como o próprio havia recomendado), Ulisses sublinha de novo a situação precária e desonrosa dos Aqueus - construindo assim o seu discurso em estrutura de anel - apelando à compaixão de Aquiles para com os companheiros de armas.

Sabendo que Aquiles não se deixaria convencer pelas estruturas do poder instituído e que, portanto, uma retórica emotiva e relacional seria mais eficaz, a estratégia de persuasão terá de ser direcionada para as suas suscetibilidades, designadamente as relações de amizade e de amor, razão pela qual a embaixada é composta por mais duas personagem - Fénix e Ájax - que se dirigem a Aquiles enfatizando a desgraça dos seus companheiros e a necessidade que estes têm de o saber de volta. 
O discurso autobiográfico de Fénix (9. 433-605) possibilita um jogo de identificação com Aquiles quer no plano pessoal, quer no plano cívico. No plano cívico porque Fénix é tutor de Aquiles e sempre o acompanhou. No plano pessoal, porque também Fénix foi vítima de alienação. Duas possibilidades se apresentam a Aquiles: ou aceita o conselho de Fénix e é honrado segundo os parâmetros definidos por Agamémnon, ou segue o caminho de intransigência de Meleagro, o exemplum dado pelo tutor.

A evocação de exempla contribui em grande medida, em primeira instância, para a validade dos argumentos do tutor; e, em última instância, para a eficácia dos mesmos na persuasão de Aquiles. Na estrutura da intervenção de Fénix são contemplados os três planos em confronto/ convívio da Ilíada: o plano humano (no qual Fénix se inscreve como exemplum), o plano divino (na alegoria das $\Lambda \imath \alpha \alpha i ́$, na qual as relações de auxílio entre os agentes merecem destaque), o plano heróico (chamando à situação o exemplum de Meleagro). 0 primeiro plano a que recorre - o humano - constitui o exemplo da sua própria vida (9. 444-94). Fénix cumpre o que a sua mãe lhe suplica (9.451). Ao aceder ao pedido de sua mãe, deitando-se com a amante de seu pai, Fénix age de acordo com os preceitos das súplicas. Porém, uma grande desgraça se abate sobre ele, no momento em que seu pai descobre o plano arquitetado por mãe e filho (9. 453-6) e roga uma maldição ao último. Esta disputa entre pai e filho durará até que Fénix decida fugir de sua casa (9. 462-3).

Ora, o exemplo de Fénix realça dois paralelos entre tutor e Aquiles. Em primeiro lugar, o desafio da autoridade. Em segundo lugar, a rejeição de súplicas por parte de alguém que não é o responsável pela situação que está na origem do desentendimento. Se Fénix, para ficar no palácio, teria de ser convencido a tal pelo pai, com o devido pedido de desculpas, Aquiles terá a legitimidade de exigir que Agamémnon venha em pessoa pedir a permanência do Pelida. Fénix foi responsável pela origem do conflito, por ter acedido às súplicas de sua mãe, mas não suportará permanecer no palácio de seu pai encolerizado (9.463). Da mesma forma, 
Aquiles, dando voz à vontade dos Aqueus perante a súplica de Crises, desafia a autoridade de Agamémnon (o rei) e perante o ultraje a que o último o submete ameaça partir (cf. 1. 169-71). Se recusar a embaixada, o Pelida seguirá os passos do seu tutor rejeitando as súplicas de amigos e parentes (9.464-5). Outro dos pontos de contato entre os dois casos é o fato de a origem do conflito ser, em ambos os casos, uma mulher cativa, uma concubina. Porém, no caso de Aquiles é a sua concubina que lhe é retirada pela figura de autoridade e não ao invés, como sucede no caso de Fénix. Este pormenor impede que a figura do pai de Fénix seja equivalente à de Agamémnon. ${ }^{8}$ Contudo, Fénix não pretende que Aquiles vire costas à comunidade aqueia. Como tal, é imperativo que o tutor demova Aquiles da sua posição irredutível.

Ao partir do seu palácio, Fénix renunciou à família e à sua riqueza. Não obstante, a sua fuga conduzi-lo-á à Ftia, onde o benévolo Peleu o acolherá com os privilégios de um filho (9.478-86). Nestes versos, estabelece-se uma cadência de relações paternais: Peleu adotou Fénix como seu filho; este, por sua vez, ama Aquiles como se fosse seu filho. É na qualidade de pai afetivo de Aquiles que Fénix o aconselha a ceder ao pedido de Agamémnon, pedido este que passa por dar ao Pelida uma das suas filhas como esposa, o que colocaria o último na figura de genro, e, portanto, com obrigações familiares para com o Atrida. É curioso notar que o discurso de Fénix é inteiramente dirigido a motivos do quadrante familiar e afetivo, onde a piedade e a concessão de favores é recorrente.

O motivo das Preces, para além de constituir o plano do divino da intervenção do tutor, prefigura relações de auxílio. As afinidades entre

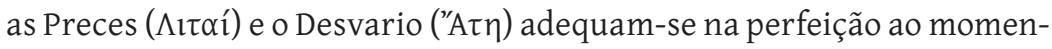
to em questão por duas vias. Em primeiro lugar, porque ao justificar o que sucedeu a Agamémnon no Canto 1 o motivo adverte o Pelida para a

8 Cf. Alden (2000: 221-6) para as afinidades entre Fénix e Aquiles. 
desgraça subjacente a uma recusa de preces. ${ }^{9}$ Em segundo lugar, porque a filiação das $\Lambda \imath \tau \alpha i ́$, filhas de Zeus, aproxima-as do estatuto de ninfas estabelecendo um paralelo entre este episódio e o de Tétis dirigindo-se

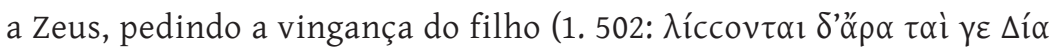

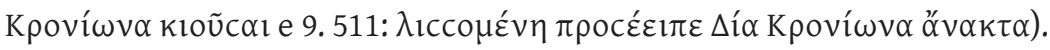
Por conseguinte, as Preces representam o que havia sido prometido a Aquiles, a honra que Zeus aceitou conceder-lhe, por meio da inspiração de um gesto humilde no soberbo Agamémnon. Por outro lado, ao lembrar o plano divino - e, concretamente, a sua mãe - Aquiles reaviva a sua escolha ao partir, o seu desejo de glória.

É no encalço desta reflexão que surge o paradigma de Meleagro, convidando Aquiles para a ponderação acerca da sua demanda heróica na esperança de que, confrontado com o exemplum mítico, o Pelida não seja capaz, como fez Meleagro, de recusar os pedidos de companheiros e familiares. ${ }^{10}$

Todavia, como é claro na intervenção de Ájax (9. 624-42), a atitude de Aquiles não é compreendida pelos companheiros. O herói repudia a conduta de Aquiles, e a sua apóstrofe dirigida a Ulisses é plena de sarcasmo (9. 624-30). No caso dos dois primeiros versos, o recurso à forma verbal íouعv (9.625), no sentido em que ecoa a primeira ameaça de partida por parte de Aquiles (1. 169-71), revela a consciência de Ájax ao perceber que Aquiles recusa o valor quantitativo da glória anunciada pelos embaixadores - os prémios oferecidos por Agamémnon - não se encontrando o Pelida na disposição de recuar.

No seguimento da ilustração dos esforços inócuos dos companheiros de Meleagro, surge Ájax, desiludido com a atitude do companheiro. Acusa Aquiles de ter virado as costas aos camaradas, o que configura

9 Cf. Thornton (1984); Crotty (1994); Alden (2000: 181-296). Para os mitos com personagens abstratas vide West, M. (1997: 373).

10 Cf. Alden (2000: 229-290). 
um ato de desrespeito absoluto pelas intocáveis normas sociais vigentes; o coração, no seu peito, que era bom, a força da sua ira tornou mau, desumano, animal. o filho de Télamon não fala por Agamémnon, mas por todos os Aqueus que terão de regressar ao combate odioso; é para com eles que Aquiles devia ser piedoso. Mas Aquiles é o contrário dis-

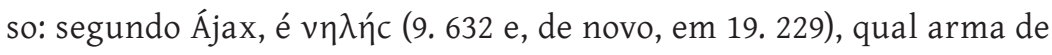
ferro e de bronze que mata sem piedade, sem remorso. Ao recusar as desculpas de Agamémnon, Aquiles está a condenar os companheiros à morte sem pestanejar e a incorrer num comportamento sobranceiro: recusar uma súplica (cf. 9. 632-8).

Ájax procura fazer entender a Aquiles quão desumano seria recusar a recompensa e permanecer apartado da batalha. Não há, do ponto de vista de Ájax, razão objetiva para concordar com Aquiles, para o compreender, pois que há quem aceite recompensas pelo homicídio de um ente querido (9.632-6). E, constatando a frieza de Aquiles, Ájax 84 dirige-lhe diretamente as suas últimas palavras antes de regressar à assembleia dos Aqueus, numa derradeira tentativa de o fazer mudar de ideias. Começa a frase com o pronome coí (9.636), como se estivesse a apontar o dedo a Aquiles em sinal de acusação e de aviso. Porém, depressa o tom se altera tomando a forma de uma derradeira súplica pela condescendência do Pelida para com os companheiros Aqueus (9. 639-40).

A palavra a que recorre no seu pedido - í $\alpha \lambda$ oc - atribui a Aquiles um estatuto divino, uma elevação de Aquiles ao plano divino: os Aqueus estariam dispostos a honrar Aquiles como a um deus. 0 recurso a um vocábulo que nos transporta para o plano divino concretiza a decisão de Aquiles relativamente às súplicas de Agamémnon tão determinante quanto a vontade divina. Não são somente os prémios que pretendem honrar Aquiles como se fosse um deus. Também o próprio se coloca próximo do plano divino quando, perante a humilhação de que foi vítima, Aquiles cessa de se sentir na obrigação de auxiliar os Aqueus. 
Ao ser varrido da comunidade, Aquiles passa a mover-se noutro plano que acentua em 9.374-5, recusando a reunião e a concórdia. A palavra

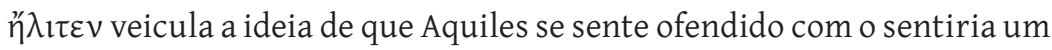
deus. É, portanto, a partir deste ponto que Aquiles assume uma posição semelhante à divina ao observar de longe o campo de batalha, tal como Zeus e os restantes deuses que se deliciam com o combate, ou sofrem com a desgraça dos seus protegidos que os faz, por fim, intervir, como é o caso da condição de regresso de Aquiles que se propõe a entrar na batalha somente quando o acampamento dos Mirmidões estiver ameaçado pelas hostes troianas (9.649-55).

O caminho para esta colocação de si próprio num plano distinto do humano é delineado nas respostas que o Pelida oferece aos pedidos dos embaixadores. A reacção de Aquiles ao discurso de Ulisses é peremptória (cf. 9. 309-11) e segue um esquema gradual na justificação da posição do Pelida. Depois de desconstruir a intenção e Agamémnon (9. 312-6), o Pelida elenca as injustiças que sofreu na guerra comandada pelos Atridas (9.318-33), criticando a praxis da sociedade monárquica em que se enquadra a narrativa. Recorrendo ao mesmo esquema de catálogo, Aquiles desvaloriza a oferta de Agamémnon, uma vez que esta não sara a $\theta u \mu \alpha \lambda \gamma \varepsilon \dot{\varepsilon} \alpha \lambda \omega \beta \eta ́ v$ (9. 387) que aquele sente, pois que que o que lhe está a ser oferecido facilmente obtém ele sem ter de se subordinar a ninguém. A abundância não é critério para aceitar, uma vez que, ainda que incontáveis, os prémios não valem a sua vida (9. 401-2, 407-8). Agamémnon procura construir uma narrativa feliz na qual Aquiles caiba como protagonista, mas o Pelida escolhe outro caminho. Ao construir uma narrativa na qual Aquiles não se quer enquadrar, Agamémnon está, mais uma vez, a contribuir para a alienação do Pelida. Pelo conteúdo da lista de presentes transparece uma clara divergência de ambos os heróis no que toca à investida contra Tróia. Agamémnon e seus conselheiros julgam que Aquiles se sente lesado somente porque lhe retiraram Briseida. 
Contudo, o que revolta Aquiles supera o ultraje pela tomada da concubina. Mais do que se sentir ofendido com a humilhação pública de que foi vítima, Aquiles sente que a ganância de Agamémnon é a razão que os trouxe a Ílion (9.312-45). A inclusão de Aquiles entre aqueles que partem para Tróia em busca de riqueza ou de posses (como o é Helena) é motivo bastante para a ofensa. Se Agamémnon pensa que o consegue persuadir com bens, engana-se, pois, como diz: "de valor comensurável à minha vida não são os tesouros/ que dizem possuir Ílion, cidadela bem habitada, dantes/ em tempo de paz" (9. 401-3). A vida de Aquiles vale mais e não será por tesouros que a irá sacrificar.

A alusão a um passado em paz coloca este episódio em confronto com a écfrase do Escudo de Aquiles (18. 483-608), designadamente os versos dedicados à descrição das duas cidades (18. 490-540). A menção da cidade em paz lembra-nos de imediato a cena do casamento descrita no escudo (18. 491-6). Ora, de casamentos tinha o Pelida acabado de falar, recusando categoricamente a celebração do matrimónio com uma das filhas de Agamémnon (9. 388-400). Porém, a alusão ao escudo pode assumir um caráter mais profundo. Lembremos que Aquiles será o detentor do escudo que recria esta mesma imagem da cidade em tempo de paz e da cidade em tempo de guerra. As duas cidades do seu escudo são a mesma em tempos diferentes: Tróia. Tróia antes da campanha aqueia: a cidade em paz; Tróia durante a campanha: a cidade em guerra. É armado com o escudo que conta a história de Ílion que Aquiles irá defrontar Heitor. E nessa mesma batalha, já junto às margens do Escamandro, num dos momentos de suspense mais notáveis da literatura que o poeta informa o leitor que era naquele mesmo lugar onde "as vestes resplandecentes/ vinham lavar as mulheres e mais belas filhas dos Troianos;/ mas isso fora antes, em tempo de paz" (22. 154-6). A importância da écfrase do escudo é, assim, tanto mais determinante na narrativa, quanto mais considerado for o seu contributo para o quadro trágico do combate entre Aquiles e Heitor. Mais, 
a legitimar a intertextualidade dos dois episódios, estão também as palavras de Ájax quando, procurando fazer Aquiles ver quão insensata é a sua recusa, recorre à imagem das indemnizações por homicídio de um familiar (9. 632-6). Na verdade, esta exata situação é central na descrição da cidade em paz do Escudo (18. 497-508). Também aqui, como notou Alden (2000: 55-60), o conflito do escudo é equiparável à zanga de Aquiles e Agamémnon.

O priamel, a 9. 379-87, condensa em si o sentimento de ultraje sentido por Aquiles no momento em que lhe é proposta a aceitação dos presentes em troca do seu regresso à batalha:

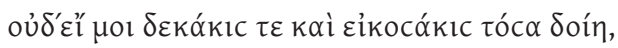

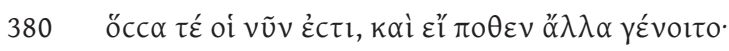

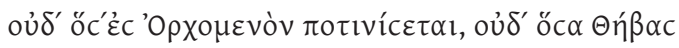

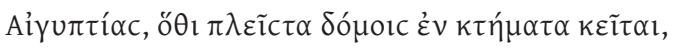

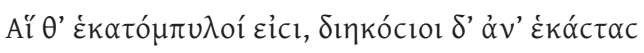

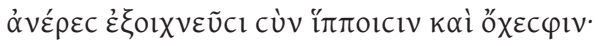
385

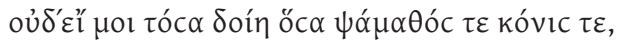

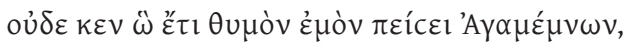

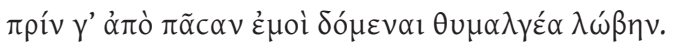

Nem que me oferecesse dez vezes mais ou vinte vezes mais 380 do que agora oferece, e que a isso acrescentasse outros dons, nem que fossem os tesouros de Orcómeno, ou da egípcia Tebas, onde nas casas jaz a maior quantidade de riqueza; Tebas com os seus cem portões, e de cada um arremetem duzentos guerreiros equipados com carros e cavalos!

385 Nem que me desse tantos presentes como grãos de pó e areia, nem assim Agamémnon conseguiria convencer o meu espírito, antes que tenha pago todo o preço daquilo que me mói o coração. 
Como se a ira e a dor crescessem a cada abordagem de Agamémnon, assim cresce o valor dos presentes que Aquiles, ainda assim, rejeita. O encadeamento do catálogo de Aquiles faz esperar, na sua torrente de orações negativas, uma recusa categórica. Todavia, no fim da sequência deparamo-nos com uma oração com $\pi$ pív (9. 387) que quebra a incondicionalidade do regresso. A iminência do regresso do filho de Peleu é mencionada propositadamente, prenunciando a sucessão crescente de cedências da parte de Aquiles perante o discurso de cada embaixador: à medida que os embaixadores se lhe dirigem, o coração de Aquiles torna-se mais flexível, mais compassivo.

Aquiles vai desconstruindo o catálogo de Agamémnon, deixando antever a razão última da sua recusa: de que lhe adianta estar agora a subjugar-se a Agamémnon se nunca poderá vir a usufruir do que lhe está a ser oferecido? ${ }^{11}$ O Pelida começa por desvalorizar a referência aos objetos, como se não fossem dignos de menção e constrói conceptual88 mente algo que supera a proposta de Agamémnon para no fim rejeitar tudo. Só aqui o Pelida revela o conhecimento do seu destino (9. 410-16) ${ }^{12}$ :

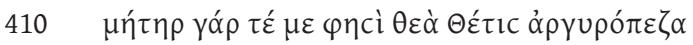

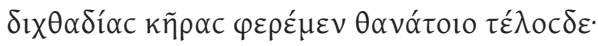

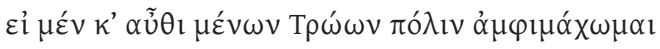

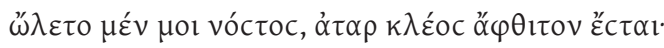

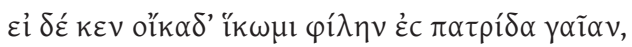

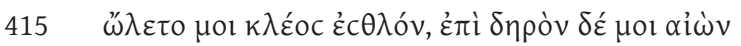

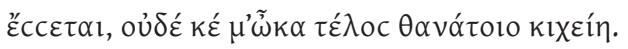

410 Na verdade me disse minha mãe, Tétis dos pés prateados, que um dual destino me leva até ao termo da morte:

se eu aqui ficar a combater em torno da cidade de Tróia,

11 Cf. Sammons (2008: 374)

12 Ibidem. 
perece o meu regresso, mas terei um renome imorredouro; porém se eu regressar a casa, para a amada terra pátria, 415 perece o meu renome glorioso, mas terei uma vida longa, e o termo da morte não virá depressa ao meu encontro.

O dual destino que foi traçado para Aquiles impede-o de aceitar a proposta de Agamémnon, uma vez que a mesma não é conciliável com nenhum dos desígnios reservados a Aquiles e entre os quais terá de optar. Se Aquiles concordar em regressar à batalha, morrerá, não podendo, assim, usufruir dos prémios; se, por outro lado, abandonar Tróia, perde não só a recompensa que Agamémnon lhe oferece - cujo valor, embora Aquiles despreze (9.378), simboliza toda a prosperidade que um homem pode alcançar - mas também a glória imortal, ímpeto último do herói superior a qualquer bem, cidade ou mulher (9.401-2). No momento em que responde a Ulisses, o Pelida parece estar decidido a partir, renunciando à demanda pela fama que uma vida curta consumada na guerra lograria. Assim, dentro da lógica da recusa em conformidade com o destino fixado a priori, ao ameaçar o abandono da investida aqueia, Aquiles determina o seu destino: voltar à Ftia. Se, na resposta a Ulisses, Aquiles se demonstra pronto para partir para a Ftia, na resposta a Fénix já assume considerar a sua decisão. Na resposta a Ájax, a decisão parece já estar tomada: ficar em Ílion mas só atacar quando Heitor estivesse perto das naus dos Mirmidões. Na verdade, esta é a última mensagem que o Pelida manda comunicar aos Aqueus (9. 649-55). Contudo, não é a que Ulisses transmite a Agamémnon (9. 677-92).

Desta forma, os demais discursos condicionam o espírito de Aquiles fazendo-o reconsiderar, optando finalmente por ficar (9. 650-1), como desenvolvemos anteriormente. São os discursos emotivos e sinceros dos dois últimos embaixadores que farão Aquiles mudar de opinião, escolher outro destino: a vida curta (quiçá, demasiado breve para tanto sofrimento), a glória imortal.

Na verdade, as palavras de Fénix e de Ájax operam uma evolução no estado de espírito de Aquiles. Se, na resposta a Ulisses, o Pelida impõe 
como condição da sua entrada na batalha o pagamento, por parte de Agamémnon, de tudo o que lhe mói o coração (9.387), na resposta a Ájax, a estrutura gramatical da premissa repete-se (9.650-2), mas a condição do regresso é, desta feita, outra:

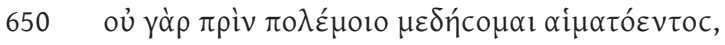

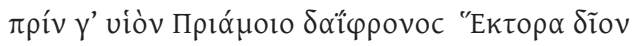

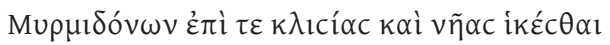

650 Antes não pensarei na guerra sangrenta, Antes que o filho do fogoso Príamo, o divino Heitor, Chegue às tendas e às naus dos Mirmidões

A mudança do íntimo de Aquiles traduz o sucesso da persuasão dos dois últimos embaixadores. Eles, que falam de graus de parentesco e de relações de amizade e companheirismo, persuadem Aquiles. No fim da embaixada, o Pelida está decidido a ficar em Tróia e a defender os companheiros (Mirmidões) caso o perigo esteja, para eles, iminente. Fica, agora, claro que Aquiles está disposto a entrar na batalha. Está tomada a decisão: Aquiles decide morrer. Ao destacar os Mirmidões como os únicos que se compromete a defender, o Pelida exclui as restantes hostes gregas do conjunto que constitui, no seu entender, a sua comunidade. Na verdade, como notou recentemente Martin West ${ }^{13}$, Aquiles aparta-se dos restantes Aqueus em diversos âmbitos. O filho de Peleu nasce de um casamento entre um mortal e uma ninfa, recebe educação de um Centauro, luta com as armas que os deuses ofereceram a Peleu no dia do seu casamento (18.83-4). O caráter sobrenatural de Aquiles legitima a sua alienação face às hostes aqueias, na medida em que o seu propósito na guerra de Tróia é distinto daquele que move os restantes companheiros. Não é por vingança ou ganância que Aquiles

13 vide supra n. 1. 
se encontra em Tróia nem para cumprir juramento algum, ao contrário dos demais Aqueus. ${ }^{14}$

Tendo em conta que Aquiles acaba por não recusar as Preces - dado que no final do discurso de Ájax, como vimos, o Pelida está determinado a ficar em Tróia - não podemos considerar, segundo a alegoria das

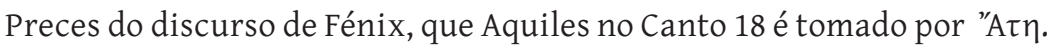
Então como justificar a ira que o enfurece e domina? Se atentarmos na narrativa que encerra a Ilíada percebemos que Aquiles se enfurece em dois momentos: quando lhe é retirada Briseida no Canto 1 e quando recebe a notícia que Pátroclo morreu em batalha no Canto 18. Assim, constitui-se um padrão de reação segundo o qual é legítimo considerar que a ira de Aquiles é despoletada quando o Pelida se vê privado de alguém que ama. Neste quadro existem, para além do âmbito das relações de amizade, amor e submissão no episódio da embaixada, outros dois níveis de relações de amor que apontam para os dois destinos entre os quais Aquiles terá de optar. O primeiro nível remete para as figuras de Aquiles e Briseida. É pelo roubo de Briseida que Aquiles se aparta do combate. Ora, este afastamento é o motivo para o envio da embaixada no Canto 9 que vai oferecer a Aquiles, como vimos, as condições para uma vida plena: a felicidade. Neste sentido, a figura de Briseida configura o móbil para uma das opções de Aquiles face ao seu destino: a vida longa e feliz. O segundo nível aponta para as figuras de Aquiles e Pátroclo. É na vingança de Pátroclo que Aquiles decide o seu destino, a opção de ficar para defender os Mirmidões e, consequentemente perecer em Tróia. E será esta relação (ou pela memória dela) que conduzirá Aquiles ao sacrifício de si mesmo. Aspeto destacado quando a Tétis, vinda em auxílio do filho, Aquiles responde que se compadece da mãe (18. 88-92):

Mas agora para que também a ti chegue a dor desmedidaPelo filho morto, que nunca mais receberás de novo,

14 Segundo o Catálogo das Mulheres Pseud-Hes. fr. 204. 76-93. 
90 regressado a casa, visto que meu ânimo me não compele A viver entre os homens e com eles coexistir, se primeiro Heitor não perder a vida golpeado pela minha lança

Neste passo, é deixada clara a escolha de Aquiles que temos vindo a desenvolver. Tal como recusou a felicidade prometida por Agamémnon, o Pelida recusa agora a convivência com os homens, numa palavra: a vida, pois mesmo se o discurso nos presenteia com uma oração condicional, é sabido (nos vv. 89-90 e no discurso posterior de Tétis vv. 95-6) que Aquiles ao matar a Heitor está a matar-se a si próprio: imagem que assume uma força dilacerante quando Aquiles ao matar Heitor se reconhece na figura do inimigo que veste a sua armadura, aquela com a qual Pátroclo morreu. 


\section{BIBLIOGRAFIA}

\section{TRADUÇÃ 0}

HOMERO (2005), Ilíada, trad. Frederico Lourenço, Lisboa.

\section{EDIÇÕES E COMENTÁRIOS}

GRIFFIN, J. (1995), Homer: Iliad IX, Oxford.

HAINSWORTH, B. (1993), The Iliad: A Commentary V. III: books 9-12, Cambridge.

Van THIEL, H. (1996), Homeri Ilias, Hildesheim, Zürich \& New York.

\section{ESTUDOS}

ALDEN, M. (2000), Homer Beside Himself: Para-narratives in the Iliad, Oxford: 1-73, 179-262.

ARIETI, J. A. (1986), “Achilles’ Alienation in Iliad 9”, CJ 82: 1-27.

DAVIES, M. (1995), “Agamemnon's Apology and the Unity of the Iliad”, CQ 45: 1-8. GOULD, J. (1973), “Hiketeia”, JHS 93: 74-103.

PEDRICK, V. (1982), "Supplication in the Iliad and the Odyssey", TAPhA 112: 125-40.

RABEL, R. J. (1991), “The Theme of Need in Iliad 9-11”, Phoenix 45: 283-295.

(1997), Plot and point of view in the Iliad, The University of Michigan Press: 115-134.

ROSNER, J. (1976), “The Speech of Phoenix: Iliad 9. 434-605”, Phoenix 30: 314-327.

SAMMONS, B. (2008), “Gift, List \& Story in Iliad 9.115-61”, CJ 103: 353-379.

THORNTON, A. (1984), Homer's Iliad: its Composition and the Motif of Supplication, Hypomnemata 81.

WEST, M. (1997), The East Face of Helicon, Oxford.

(2011), The Making of the Iliad, Oxford.

WILSON, J. (1991), “Negative $\pi \rho i ́ v$ clauses and the Rhetoric of Achilles”, Glotta 69: $175-83$. 